\title{
DYNAMIC INSTITUTIONALIZATION: THE FOUNDATIONS OF JAPAN'S RADIOACTIVE PROBLEM
}

\author{
A Thesis \\ submitted to the Faculty of the \\ Graduate School of Arts and Sciences \\ of Georgetown University \\ in partial fulfillment of the requirements for the \\ degree of \\ Master of Arts \\ in Asian Studies
}

By

Hayate Nicholas Kodama, B.A.

Washington, D.C.

October 2, 2017 
Copyright 2017 by Hayate Nicholas Kodama All Rights Reserved 


\title{
DYNAMIC INSTITUTIONALIZATION: THE FOUNDATIONS OF JAPAN'S RADIOACTIVE PROBLEM
}

\author{
Hayate Nicholas Kodama, B.A.
}

Thesis Advisor: Victor D. Cha, Ph.D.

\begin{abstract}
This thesis examines Japan's policies of implementing a closed nuclear fuel cycle and nuclear hedging. Many scholars have argued that Japan specifically pursues closed fuel cycle development in order to maintain the technologies necessary to build nuclear weapons. However, closer examination of the development of Japan's nuclear industry shows that although Japan does indeed follow a strategy of nuclear hedging, Japan's continued development of closed fuel cycle technologies is not driven by the goal of maintaining a latent nuclear weapons capability. To illustrate this point, this thesis presents a conceptual framework called "dynamic institutionalization" to explain the origins of Japan's nuclear policies and the different sets of institutionalized pressures and constraints that have perpetuated these policies over time. The primary motive behind Japan's initial pursuit of a closed fuel cycle was to increase energy independence, but difficulties in implementing key technologies and domestic political pressures have turned reprocessing into Japan's de facto spent fuel management solution. On the other hand, Japan's strategy of nuclear hedging was institutionalized following the explicit extension of the U.S. nuclear umbrella to Japan in 1965. This hedge is perpetuated by the calculus that although Japan possesses the capability to develop nuclear weapons, its security is best guaranteed through reliance on U.S. extended deterrence. By separating the policy of pursuing a closed fuel cycle from the strategic calculus of nuclear hedging, this thesis provides a comprehensive assessment of the different variables perpetuating Japan's nuclear policies.
\end{abstract}


Reassurance of U.S. extended deterrence plays an important role in dissuading Japan from pursuing the nuclear option, but it has little effect on Japan's closed fuel cycle ambitions. 


\section{TABLE OF CONTENTS}

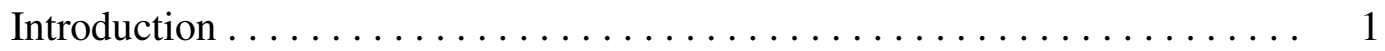

Literature Review: Nuclear Hedging and Closed Fuel Cycles . . . . . . . . . . 4

Conceptual Framework: Dynamic Institutionalization . . . . . . . . . 7

Strategic Challenges and Nuclear Age Solutions . . . . . . . . . . . 11

Institutionalizing Nuclear Policy $\ldots \ldots \ldots \ldots \ldots \ldots \ldots \ldots \ldots \ldots \ldots$

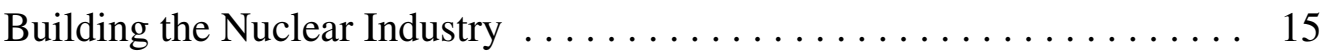

The Nuclear Hedge ....................... 22

Institutions, Interest, and Stakeholders $\ldots \ldots \ldots \ldots \ldots \ldots \ldots$

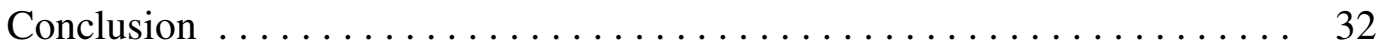

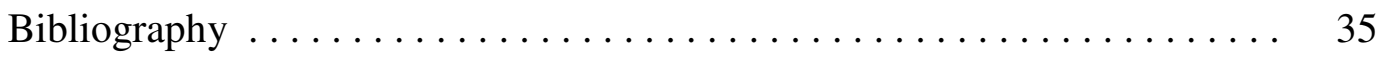




\section{Introduction}

In 2018, Japan plans to begin operations at the Rokkasho Reprocessing Plant in Aomori Prefecture. This facility is designed to extract fissile material from spent nuclear fuel for further use in nuclear reactors. In theory, this would allow Japan to reduce its dependence on uranium imports while increasing the amount of energy that can be harnessed from nuclear fuel. The Rokkasho Reprocessing Plant is one aspect of Japan's overall pursuit of a closed nuclear fuel cycle, which while ostensibly for civilian purposes, involves many technologies and processes directly applicable to the development of nuclear weapons. ${ }^{1}$ Particular concern surrounds one key product of reprocessing: Separated plutonium. Japan already possesses a stockpile of fortyseven tons of separated plutonium (eleven of which are stored within Japan) and the Rokkasho Reprocessing Plant has a designed output of up to eight tons of separated plutonium per year. If this facility begins operations as scheduled, then Japan's stockpile of weapons-useable plutonium will increase dramatically.

This issue has important security implications beyond Japan's borders. Japan's large stockpile of separated plutonium raises serious concerns about the potential diversion of nuclear materials for weapons purposes and its vulnerability to theft by non-state actors. Contrary to common belief, nuclear materials are rarely perfectly accounted for; there is often a margin of error, referred to as materials unaccounted for (MUF), when managing stockpiles. The dangers of a large stockpile of fissile material are therefore arithmetic: The larger the stockpile, the

\footnotetext{
${ }^{1}$ The closed fuel cycle involves reprocessing spent fuel from nuclear power plants to separate trace quantities of fissile uranium and plutonium. This fissile material is then either fabricated into mixed-oxide fuel (MOX fuel) to be used in commercial nuclear reactors, or used in specialized fast breeder reactors to "breed" additional plutonium from uranium-238. This additional plutonium can then be fabricated into fuel rods for use in commercial reactors. By contrast, the open fuel cycle simply involves the permanent disposal of spent fuel after use in nuclear reactors. For an overview of the closed fuel cycle process in Japan, see: Japan Nuclear Fuel Limited, "Rokkasho Reprocessing Plant,” 2014, http://www.jnfl.co.jp/en/about/publication/file/reprocessing_plant.pdf.
} 
greater the margin of error; the greater the margin of error, the more likely it is that a bomb'sworth of material could be lost and remain undetected. ${ }^{2}$ Moreover, South Korea and Taiwan have cited Japan's reprocessing program as a reason why they too should develop reprocessing technologies. ${ }^{3}$ The notable difference between Japan, South Korea, and Taiwan is that the latter two have historically pursued nuclear weapons development. ${ }^{4}$

This paper examines why Japan continues to pursue closed fuel cycle technologies. The answer to this question is not as straightforward as it may initially seem. With the shutdown of most of Japan's nuclear power plants following the 2011 Fukushima Daiichi meltdown, there is no foreseeable need for the separated plutonium Japan has stockpiled for fuel purposes - let alone the additional eight tons per year that the Rokkasho Reprocessing Plant would produce once it becomes operational. The cost of fabricating fuel from separated plutonium is also vastly more expensive than the use of uranium in an open fuel cycle. ${ }^{5}$ Many have used the notion of a "nuclear hedge" to explain Japan's continued pursuit of closed fuel cycle technologies, arguing that Japan does so to maintain a latent nuclear weapons capability. However, this explanation is also insufficient. While nuclear hedging may have been a motivating factor in the early years of Japan's nuclear industry, the extent to which Japan has pursued closed fuel cycle technologies far exceeds what would be necessary for a latent nuclear weapons capability, and countries with nuclear industries far less advanced than Japan's have successfully developed nuclear weapons.

\footnotetext{
${ }^{2}$ Losses are often attributed to the handling and processing of materials, as well as naturally occurring radioactive decay. Nonetheless, these benign losses in material make diversion for nefarious purposes harder to detect. For more, see: Henry D. Sokolski, Nuclear Weapons Material Gone Missing: What Does History Teach? (Carlisle: U.S. Army War College Press, 2014).

${ }^{3}$ Henry D. Sokolski, “A Plutonium-Rich Asia," National Review, September 24, 2014; “Taiwan Wants to Send Nuclear Waste Overseas for Reprocessing," The Japan Times, February 18, 2015.

${ }^{4}$ For a brief overview of various states' nuclear weapons ambitions, see Alexandre Debs and Nuno P. Monteiro, Nuclear Politics: The Strategic Causes of Proliferation (New York: Cambridge University Press, 2017).

${ }^{5}$ Matthew Bunn et al., "The Economics of Reprocessing vs. Direct Disposal of Spent Nuclear Fuel" (Cambridge:

Project on Managing the Atom, Belfer Center for Science and International Affairs, 2003).
} 
The primary reason why Japan continues to develop closed fuel cycle technologies is because it has become institutionalized into Japan's nuclear industry as a way to manage spent fuel. The latent nuclear weapons capability provided by Japan's advanced nuclear industry has been incorporated into Japan's strategy of nuclear hedging, but it is important to note that the structure of Japan's nuclear industry and the strategy of nuclear hedging were institutionalized on separate paths. Analytically, there is a need to separate the pressures and constraints driving Japan's strategy of nuclear hedging from those that perpetuate the policies of closed fuel cycle development. The development of a closed fuel cycle makes possible Japan's strategy of nuclear hedging, but nuclear hedging is not the reason behind Japan's development of a closed fuel cycle.

On the civilian side, Japan's development of closed fuel cycle technologies was motivated by an interest in decreasing dependence on energy imports. The initial decision to pursue these technologies became institutionalized through a variety of political, financial, diplomatic, and structural arrangements. Over time, these institutional arrangements have turned reprocessing into Japan's de facto spent fuel management solution. Today, Japan faces significant pressures to continue its pursuit of a closed fuel cycle despite the fact that doing so makes little sense from an economic perspective. On the other hand, Japan's policy of nuclear hedging - that is, possessing a latent nuclear weapons capability while relying on U.S. extended deterrence - has become institutionalized into Japan's security strategy. Underlying this hedging posture is the strategic calculus that although Japan maintains the potential to develop nuclear weapons due to its advanced nuclear industry, it is not in Japan's interest to exercise its nuclear option. Through adherence to the terms of the Treaty on the Non-Proliferation of Nuclear Weapons (Non-Proliferation Treaty, or NPT), International Atomic Energy Agency (IAEA) 
safeguards, and Japan's own Three Non-Nuclear Principles, Japan has signaled its intention not to develop nuclear weapons. At the same time, however, Japanese policymakers have frequently reiterated the technical capability and constitutional prerogative for Japan to develop nuclear weapons if necessary. Implicit in these statements is the notion that if Japan's security situation were to change - either through a weakening of U.S. deterrence or increased threats from neighboring states - then Japan may rethink its non-nuclear choice.

This thesis will begin with a brief review of the existing literature on Japan's nuclear policies. It then presents a conceptual framework, called "dynamic institutionalization," to show how continuities in Japan's nuclear policies across time can be explained by institutionalized pressures and constraints. Next, this thesis will examine the strategic motives behind Japan's initial pursuit of closed fuel cycle technologies. It will then trace the process by which various institutionalized pressures and constraints have formed over time to perpetuate the policies of closed fuel cycle development and nuclear hedging, and examine the factors that may cause these policies to shift in the future. Finally, it will conclude with implications this argument has for U.S. policy.

\section{Literature Review: Nuclear Hedging and Closed Fuel Cycles}

The literature on Japan's nuclear policies can generally be divided into two analytical approaches. One approach focuses on the international pressures and constraints influencing Japan's security and its maintenance of a nuclear hedge, while the other stresses the domestic factors behind the pursuit of closed fuel cycle technologies and various norms against the development of nuclear weapons. However, while these two approaches provide important 
insights into various aspects of Japan's nuclear policies, neither one provides a comprehensive explanation of Japan's policies of nuclear hedging and closed fuel cycle development.

Much of the literature on Japan's nuclear hedge focuses on the factors that determine whether Japan would turn its latent nuclear weapons capability into a fully-fledged nuclear arsenal. ${ }^{6}$ The idea of a nuclear-armed Japan is not a new one, and is one that is firmly rooted in structural realist theories of international relations. For many structural realists, post-World War II Japan has been a rather perplexing anomaly. Japan's decision to eschew military force despite emerging as an economic superpower contradicted the commonly held assumption that states would develop military capabilities commensurate with their economic strength. Writing about Japan in the post-Cold War era, Kenneth Waltz noted that, "one may wonder how a state with the economic capability of a great power can refrain from arming itself with the weapons that have served so well as the great deterrent."7 Scholars who have written about Japan's nuclear hedge answer Waltz's rhetorical question by noting that the "great deterrent" of the U.S. nuclear umbrella has served Japan so well that the political and economic costs of developing nuclear weapons are not worth any marginal benefit to Japan's security. Indeed, a common thread in the literature on Japan's nuclear hedge is the central role of the U.S.-Japan alliance and U.S.

\footnotetext{
${ }^{6}$ Examples include: Richard J. Samuels and James L. Schoff, “Japan's Nuclear Hedge: Beyond 'Allergy' and Breakout," in Asia in the Second Nuclear Age, ed. Ashley J. Tellis (Seattle: National Bureau of Asian Research, 2013), 233-64; James L. Schoff, "Changing Perceptions of Extended Deterrence in Japan," and James R. Holmes and Toshi Yoshihara, "Thinking About the Unthinkable: Tokyo's Nuclear Option," in Strategy in the Second Nuclear Age: Power, Ambition, and the Ultimate Weapon, eds. Toshi Yoshihara and James R. Holmes (Washington, D.C.: Georgetown University Press, 2012), 99-113, 115-132; Kurt M. Campbell and Tsuyoshi Sunohara, "Japan: Thinking the Unthinkable," in The Nuclear Tipping Point: Why States Reconsider Their Nuclear Choices, eds. Kurt M. Campbell, Robert J. Einhorn, and Mitchell Reiss (Washington, D.C.: Brookings Institution Press, 2004), 218-53; Benjamin L. Self and Jeffrey W. Thompson, eds., Japan's Nuclear Option: Security, Politics, and Policy in the 21st Century (Washington, D.C.: The Henry L. Stimson Center, 2003).

${ }^{7}$ Kenneth N. Waltz, "The Emerging Structure of International Politics," International Security 18, no. 2 (Fall 1993): 64.
} 
extended deterrence. As long as the U.S. nuclear umbrella remains credible, Japan will forego developing nuclear weapons. ${ }^{8}$

The literature on Japan's nuclear hedge illustrates the strategic imperatives for the United States to maintain the credibility of its security commitments, but it does little to shed light on exactly why Japan continues to pursue closed fuel cycle technologies. While it is possible that one reason why Japan possesses a nuclear industry is so that it has a latent nuclear weapons capability, the extent to which Japan has pursued closed fuel cycle technologies is far beyond and in some cases irrelevant - to what is necessary for Japan to acquire nuclear weapons. ${ }^{9}$ There is no explanation as to why a state would continue to devote significant material resources to a program that provides little benefit to Japanese security.

Many analysts from the nuclear power and nonproliferation communities have written about the technical and domestic political factors motivating Japan's decision to continue the development of closed fuel cycle technologies. ${ }^{10}$ These factors include bureaucratic inertia, a lack of oversight in the research and development process, financial incentives given to local communities that agree to host nuclear facilities, and the use of reprocessing as a de facto storage method for spent fuel. Because of these pressures, the Japanese government would need to overcome significant obstacles in order to abandon nuclear reprocessing. However, what is

\footnotetext{
${ }^{8}$ In addition to the previously cited articles in fn. 6, see also: Robert J. Art, "The United States and the Rise of China: Implications for the Long Haul," Political Science Quarterly 125, no. 3 (Fall 2010): 378-79.

${ }^{9}$ Although there is some debate on this point, many argue that plutonium extracted from spent fuel in civilian nuclear reactors would not be suitable for nuclear weapons. This is due to a higher concentration of plutonium-240 (as opposed to plutonium-239) present in spent fuel rods. As a self-fissioning isotope, plutonium-240 may cause a nuclear device to detonate prematurely, significantly reducing the total yield of the device. J. Carson Mark, Frank von Hippel, and Edward Lyman, "Explosive Properties of Reactor-Grade Plutonium," Science \& Global Security 17, no. 2-3 (2009): 170-85.

${ }^{10}$ Examples include: Tatsujiro Suzuki, "The Fast Reactor and Its Fuel Cycle Developments in Japan: Can Japan Unlock Its Development Path?," Science \& Global Security 17, no. 1 (2009): 68-76; Masufumi Takubo and Frank von Hippel, "Ending Reprocessing in Japan: An Alternative Approach to Managing Japan's Spent Nuclear Fuel and Separated Plutonium" (International Panel on Fissile Materials, November 2013); James M. Acton, "Wagging the Plutonium Dog: Japanese Domestic Politics and Its International Security Implications" (Washington D.C.: The Carnegie Endowment for International Peace, 2015); Masafumi Takubo, "Wake Up, Stop Dreaming: Reassessing Japan's Reprocessing Program,” The Nonproliferation Review 15, no. 1 (March 2008): 71-94.
} 
lacking from much of these analyses is the strategic context behind the initial decision to pursue a closed fuel cycle and the implications advanced nuclear technologies have for Japanese security policy. Understanding the original motives behind reprocessing and its strategic implications rather than simply tracing existing domestic pressures and constraints is essential for developing a full picture of how these nuclear polices became institutionalized within Japan.

Finally, some scholars have cited Japan's antinuclear sentiments and antimilitarist norms as reasons why Japan will not develop nuclear weapons despite having the technical capability to do so. ${ }^{11}$ The collective memories of the atomic bombings of Hiroshima and Nagasaki, the irradiation of the Daigo Fukuryū Maru (Lucky Dragon Five) fishing vessel following U.S. nuclear testing at Bikini Atoll, and the meltdown of the Fukushima Daiichi nuclear reactor following the March 11, 2011 earthquake and tsunami serve as stark reminders of the dangers of nuclear weapons and nuclear energy. However, these constructivist approaches are unable to explain why a country with strong antinuclear and antimilitarist norms maintains one of the world's most advanced civilian nuclear industries and relies heavily on the U.S. nuclear umbrella.

\section{Conceptual Framework: Dynamic Institutionalization}

The dichotomy in the existing literature on Japan's nuclear policies is indicative of one of the fundamental dilemmas in the study of international relations: the question of whether policy is driven primarily by internal or external factors. Various theories and paradigms have been

\footnotetext{
${ }^{11}$ For example, see: Matake Kamiya, "Nuclear Japan: Oxymoron or Coming Soon?," The Washington Quarterly 26, no. 1 (December 2002): 63-75. For analysis of Japan's antimilitarist norms, see: Andrew Oros, Normalizing Japan: Politics, Identity, and the Evolution of Security Practice (Stanford: Stanford University Press, 2008); Thomas U. Berger, Cultures of Antimilitarism: National Security in Germany and Japan (Baltimore: Johns Hopkins University Press, 1998).
} 
developed to frame this interaction between international and domestic variables. For example, structural realism uses a "top down" approach where systemic external factors - in particular, the relative distribution of material power - are the primary determinants of policy outcomes with domestic factors playing a secondary, or even nonexistent, role. ${ }^{12}$ Liberal theories of international relations, on the other hand, take a "bottom up" approach by stressing the importance of policy preferences among individuals and private groups in shaping policy outcomes. ${ }^{13}$ Finally, constructivist theories take a similar "top down" approach to structural realism, but stress the importance of normative and ideational factors in shaping how domestic policymaking bodies perceive and respond to international pressures. ${ }^{14}$

One characteristic that many of these paradigms share is that their policy-making processes are linear: There is a one-way causative link between the external and internal (and in the case of constructivism, normative) variables that generate policy outcomes. These frameworks lack temporal definition: They can explain the causative logic behind a given policy at a given point in time, but they do not include mechanisms to account for continuity in policy across time. Under these frameworks, continuity in policy is explained exogenously. As long as the inputs in the policy-making framework remain the same, the policy outcome will remain the same. In reality, however, it is widely acknowledged that past precedence plays an important role in policymaking. Common phrases such as "bureaucratic inertia" and the "stickiness" of

\footnotetext{
${ }^{12}$ Neorealists like Kenneth Waltz leave the issue of explaining state behavior untouched, arguing that while the behavior of states is influenced by structural factors, actual policy outcomes should be examined through "analysis" rather than through theory; offensive realists argue that because security in the international system is scarce, states must act according to the pressures of the international system in order to survive; and defensive realists assert that security is more plentiful in the international system, and therefore states have more leeway in responding to international systemic pressures. See: Kenneth N. Waltz, Theory of International Politics (Boston: McGraw-Hill, 1979); John J. Mearsheimer, The Tragedy of Great Power Politics, Updated edition (New York: W.W. Norton \& Company, 2014); Stephen M. Walt, "International Relations: One World, Many Theories," Foreign Policy, no. 110 (1998): 29-46.

${ }^{13}$ Andrew Moravcsik, "Taking Preferences Seriously: A Liberal Theory of International Politics," International Organization 51, no. 4 (Autumn 1997): 513-53.

${ }_{14}$ Alexander Wendt, "Anarchy Is What States Make of It: The Social Construction of Power Politics," International Organization 46, no. 2 (Spring 1992): 391-425.
} 
institutions illustrate this fact. Furthermore, just because a policy serves a particular purpose today does not necessarily mean it was originally implemented for that reason. A dynamic conception of the policy-making process that incorporates policy precedents as a variable in present policymaking is therefore necessary.

This thesis presents a new framework to analyze Japanese nuclear policies - a process called "dynamic institutionalization": The initial motives behind pursuing a closed fuel cycle came from the pressures and constraints of the international system. In the aftermath of World War II, Japan remained militarily weak and heavily dependent on energy imports. These pressures and constraints were the inputs into Japan's domestic policy-making bodies, which responded with the decision to develop advanced nuclear technologies. At the time, mastering closed fuel cycle technologies was seen as a way for Japan to promote its security interests through a latent nuclear weapons capability and enhance energy security by decreasing dependence on imports. The dynamic element of this framework stems from the fact that the initial decision to develop closed fuel cycle technologies led to the formation of additional institutionalized pressures and constraints on policymaking (fig. 1). These "institutions" were not only organizational structures, but also legal restrictions, political arrangements, normative constraints, financial pressures, and technical requirements for managing nuclear materials. These institutionalized pressures and constraints have served to perpetuate Japan's policies of closed fuel cycle development and nuclear hedging. Japan continues to develop closed fuel cycle technologies today, but it no longer does so for energy independence or security reasons. Instead, it is because of the various institutionalized pressures that have accumulated over time. 
Structural Realism

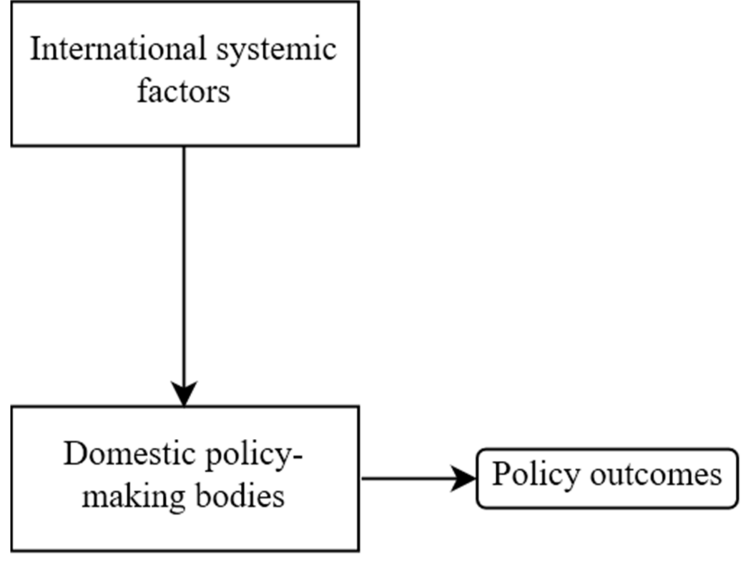

Constructivism

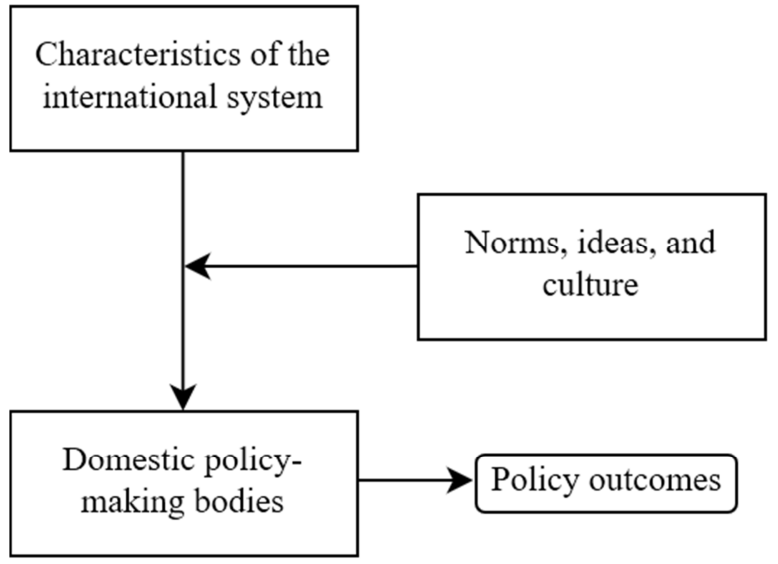

Liberalism

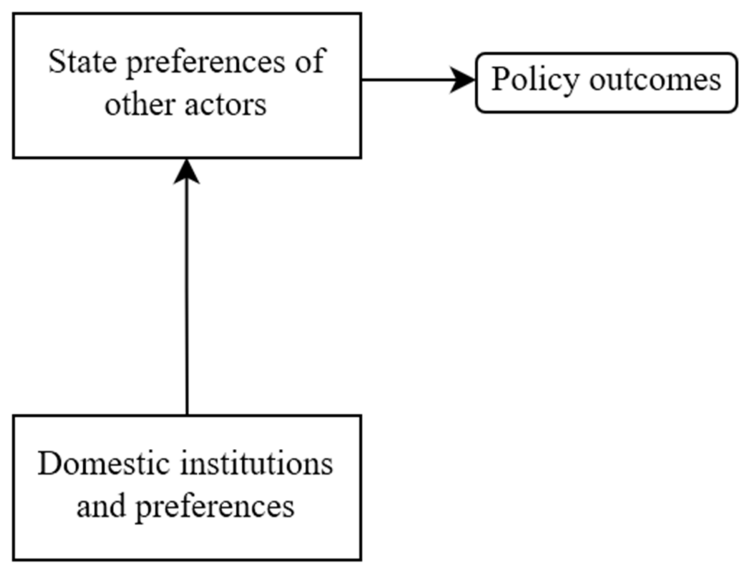

Dynamic Institutionalization

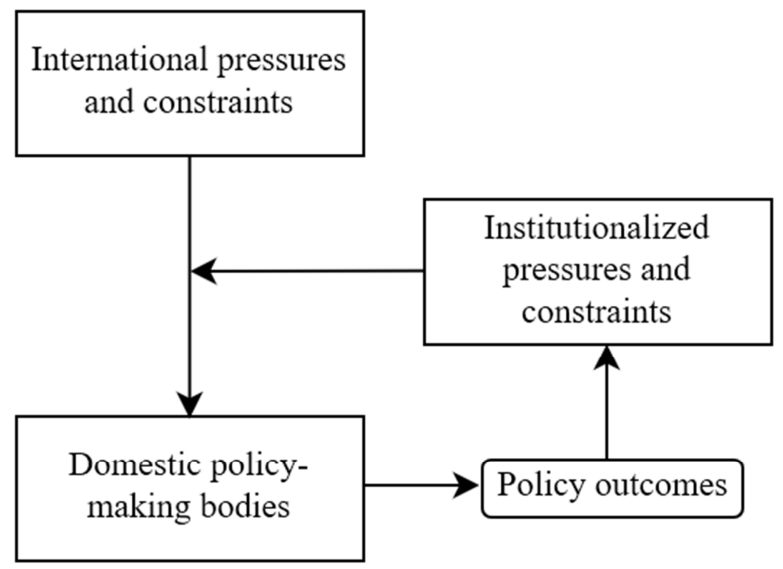

Fig. 1: Comparison of policy-making frameworks.

The framework of dynamic institutionalization provides a more complete explanation for Japan's policies of nuclear hedging and closed fuel cycle development. It modifies colloquial terms such as "bureaucratic inertia" and "institutional stickiness" into more methodologically rigorous causal mechanisms and incorporates an endogenous means of explaining continuity in policy. Japan's nuclear policies cannot be explained solely by domestic or international variables, or by tracing the rationale behind these policies that are present at any given time. 
Instead, they should be explained as a dynamic process that incorporates the relationship between domestic, international, and institutionalized variables across time.

\section{Strategic Challenges and Nuclear Age Solutions}

Since the birth of modern Japan at the end of the Meiji Restoration, Japanese policymakers have faced the dilemma of how Japan could become a secure, prosperous state while lacking the strategic depth and natural resources necessary to support such ends. Japan's responses to this dilemma have changed over the years, but as Richard Samuels notes, a common thread linking these responses was the twin pursuit of autonomy and prestige. ${ }^{15}$ The intersection between this age-old strategic challenge, and the promises and threats of the nuclear age had a direct impact on the formative years of Japan's nuclear industry.

Imperial Japanese policymakers answered the strategic challenge of achieving security and prosperity by pursuing autarky. In the early $20^{\text {th }}$ century, the Japanese Empire spread throughout East Asia in an effort to secure the resources and strategic depth necessary to support the home islands. However, as is well known from the history of World War II, autarky was not the answer. Faced with crushing defeat, postwar Japan accepted the reality of its geopolitical situation: The means to support Japanese power would have to come from without rather than within. Since then, Japan has maintained - albeit somewhat reluctantly - a dependence on outside sources for military power, wealth, and energy.

\footnotetext{
${ }^{15}$ Richard J. Samuels, Securing Japan: Tokyo's Grand Strategy and the Future of East Asia (Ithaca: Cornell University Press, 2008), 6.
} 
The U.S.-Japan alliance has served as the cornerstone of Japanese security since its establishment in $1960 .{ }^{16}$ This alliance was a key component of the so-called Yoshida Doctrine, a political-compromise-turned-strategy in which Japan would rely on the United States for security, maintain minimal defense capabilities, and pursue economic development. Relying on the United States for security would eliminate the need for Japan to pursue financially and politically costly rearmament, allowing Japan to focus its efforts on recovering from the destruction of World War II. In exchange, the United States maintained bases on Japanese territory as a key element of U.S. force projection in Asia, and kept Japan within its Cold War sphere of influence. ${ }^{17}$ However, despite the United States' strategic imperatives to protect Japan, concerns about the credibility of its defense commitments remained, and Japanese policymakers understood the risks of depending solely on the alliance for security. From the early years of the Cold War up to the present day, Japan has continually sought reassurances from the United States of its security commitments, including its willingness to use nuclear weapons if necessary to defend Japan.

Dependence on energy imports has been another persistent concern for modern Japanese policymakers. Japan's decision to attack Pearl Harbor, after all, was ultimately made after the U.S. embargo on oil and gasoline. Japan's dependence on energy imports continued through the postwar years, with an especially strong reliance on fossil fuels from geopolitically unstable regions such as the Middle East. ${ }^{18}$ Moreover, Japan's mountainous terrain and small size limits the land area that can be utilized for power generation. Nuclear power was therefore seen as an

\footnotetext{
${ }^{16}$ The original 1952 Security Treaty between the United States and Japan did not include an explicit security commitment by the United States to defend Japan.

${ }^{17}$ For more on the United States' interest in keeping Japan within its sphere of influence during the Cold War, see: Victor D. Cha, Powerplay: The Origins of the American Alliance System in Asia (Princeton: Princeton University Press, 2016).

${ }^{18}$ In 2015, roughly 80 percent of Japan's oil came from the Middle East. "Energy Policies of IEA Countries: Japan" (Paris: International Energy Agency, 2016), ch 5.
} 
important way for Japan to meet its energy needs and promote energy independence. Before power plants were shut down following the March 11, 2011 disasters, nuclear power provided 15 percent of Japan's total annual energy supply. However, the power generation capacity lost from the shutdown of nuclear power plants was largely replaced with fossil fuels. By 2015, 93.7 percent of Japan's energy came from fossil fuels. ${ }^{19}$

These strategic imperatives have influenced Japan's pursuit of a closed fuel cycle. In both cases, this pursuit served as a way to mitigate Japan's dependence on external sources for security and prosperity: A latent nuclear weapons capability would theoretically allow Japan to guarantee its survival in the event of a severe security crisis, and the development of a closed fuel cycle could also provide a way for Japan to further reduce its dependence on energy imports by allowing it to extract additional fissile material from spent fuel rods. These external pressures, however, are not the sole determinants of policy outcomes, and these pressures have changed in subtle but significant ways. The necessity and ability of nuclear weapons to guarantee security in the post-Cold War era has diminished with the spread of international institutions, economic interdependence, and the rise of asymmetric warfare and "gray-zone" conflicts. Nuclear weapons alone cannot be the sole guarantor of Japan's security. ${ }^{20}$ Additionally, the availability of large quantities of uranium ore from geopolitically stable states like Australia and Canada, as well as rapid advancements in renewable energy technologies, have weakened the energy security rationale for reprocessing spent fuel. ${ }^{21}$ Explaining the continuities in Japan's nuclear policies

\footnotetext{
${ }^{19}$ Ibid., ch. 2

${ }^{20}$ For an analysis of how Japan's strategic thinking towards deterrence has changed in the post-Cold War era, see: Sugio Takahashi, "Ballistic Missile Defense in Japan Deterrence and Military Transformation," Asie. Visions 59 / Proliferation Papers 44, December 2012.

${ }^{21}$ Of the world's known recoverable uranium resources, 29 percent are in Australia and 9 percent are in Canada. “Uranium Supplies: Supply of Uranium,” World Nuclear Association, December 2016, http://www.worldnuclear.org/information-library/nuclear-fuel-cycle/uranium-resources/supply-of-uranium.aspx.
} 
despite evolving international pressures therefore requires examining the role of domestic factors, and most importantly, the process of dynamic institutionalization.

\section{Institutionalizing Nuclear Policy}

Having established the strategic motives influencing Japan's decision to pursue closed fuel cycle technologies, it is now possible to trace the process by which these influences became institutionalized into the foundations of Japan's nuclear industry and strategy. On this point, it is important to reiterate that there are two separate but parallel components to the dynamic institutionalization of Japan's nuclear policies. The first is the institutionalization of reprocessing into the structure of Japan's nuclear industry. Japan initially pursued reprocessing as a way to achieve a higher degree of energy independence, but difficulties in fully implementing closed fuel cycle technologies gradually turned reprocessing into a means of managing spent fuel and placating local communities' opposition to nuclear power plants. The second component is the institutionalization of the nuclear hedge into Japanese security policy. Although Japan has the capability to develop nuclear weapons, it has fully institutionalized its non-nuclear choice through various nonproliferation safeguards and reliance on U.S. extended deterrence. However, despite this, policymakers have frequently noted that Japan possesses the technical ability to develop nuclear weapons if it chose to do so. These reminders of a Japanese nuclear option have been used to further emphasize the importance of the U.S. nuclear umbrella in Japan's strategic calculus. These two nuclear policies both have their origins in the 1950s and 1960s, but have become institutionalized separately, with the structure of the nuclear industry having little direct relationship with Japan's nuclear hedging strategy. 


\section{Building the Nuclear Industry}

The Japanese nuclear industry traces its origins to the 1955 Atomic Energy Basic Act, which established the Japan Atomic Energy Commission (JAEC) and the Nuclear Safety Commission for the purposes of carrying out the research, development, utilization, and operation of nuclear energy in Japan. ${ }^{22}$ In its very first long-term planning document, the JAEC identified the goals of developing breeder reactors and reprocessing capabilities as a way for Japan to be as self-sufficient as possible in the supply of fuel for nuclear reactors. ${ }^{23}$ It would take another decade for the first nuclear reactor to become operational, and two decades for Japan's first reprocessing plant (Tokai Reprocessing Plant) and experimental breeder reactor (Jōyō Fast Breeder Reactor) to begin operations, but it was clear from the start that energy independence was a key concern for Japanese policymakers. These concerns were fueled in part by the global perception that the supply of easily recoverable high grade uranium ore was relatively scarce. ${ }^{24}$ By developing reprocessing and breeder reactor technologies, states could not only maximize their use of enriched uranium-235, but could also utilize the cheaper and more abundant uranium-238 isotope for energy. ${ }^{25}$

Civilian nuclear cooperation between the United States and Japan played an important role in the development of the Japanese nuclear industry. Technical assistance in developing nuclear technologies originated in President Dwight Eisenhower's “Atoms for Peace" policy to

\footnotetext{
22 “Atomic Energy Basic Act (Act No. 186 of December 19, 1955)" (Japanese Law Translation, Ministry of Justice), accessed May 7, 2017, http://www.japaneselawtranslation.go.jp/law/detail/?id=2233\&vm=04\&re=02.

23 "Genshiryoku no kenkyū, kaihatsu oyobi riyō ni kansuru chōki keikaku [Long Term Plan on Nuclear Research, Development, and Use]" (Japan Atomic Energy Commission, 1956),

http://www.aec.go.jp/jicst/NC/tyoki/tyoki1956/chokei.htm.

${ }^{24}$ Frank von Hippel, "Overview: The Rise and Fall of Plutonium Breeder Reactors," in Fast Breeder Reactor Programs: History and Status, eds. Thomas B. Cochran et al. (International Panel on Fissile Materials, 2010), 5.

${ }^{25}$ Uranium ore naturally contains approximately 99.3 percent uranium- 238 and only 0.7 percent uranium- 235 . In fast breeder reactors, uranium-238 transmutates into plutonium, a fissile material that can be used in nuclear fuels.
} 
promote the peaceful use of nuclear power worldwide. By 1956, Japan had already formed five joint ventures with American and British nuclear manufacturers, and through these joint ventures Japan was able to acquire and ultimately indigenize civilian nuclear technologies. ${ }^{26}$ Cooperation between the United States and Japan also extended to the development of reprocessing technologies. In 1977, Japan received permission and technical assistance to begin reprocessing up to ninety-nine tons of U.S.-origin fuel at Tokai Reprocessing Plant. ${ }^{27}$ In 1988 the "Section 123 Agreement," named after Section 123 of the U.S. Atomic Energy Act, expanded these terms to give Japan blanket permission to reprocess spent fuel domestically and also transfer spent fuel to the United Kingdom or France for reprocessing. ${ }^{28}$ This agreement nominally has a term of thirty years, but will be renewed automatically unless either side makes a request for renegotiation.

A key assumption held by the Japanese government during the formative years of Japan's nuclear industry was that fast breeder reactors (FBR) would become commercially viable within two decades. In the JAEC's 1956 long-term plan, it was predicted that commercialized breeder reactors would become operational by the 1970 s. ${ }^{29}$ As such, the development of Japan's nuclear infrastructure proceeded under the assumption that Japan would eventually implement a closed nuclear fuel cycle. In reality, the commercialization of FBRs has faced significant obstacles. Many of these obstacles stem from the fact that FBRs require the use of liquid sodium as a coolant. Technical issues involving the use of sodium include the risk of fires due to leaks and difficulties in maintaining reactor hardware due to the fact that the sodium in the reactor vessel is

\footnotetext{
${ }^{26}$ William R. Nester, Japanese Industrial Targeting: The Neomercantilist Path to Economic Superpower (New York: St. Martin's Press, 1991), 132-33.

${ }^{27}$ For the text of the agreement, see: "Japan-United States: Agreement on Reprocessing Nuclear Material of U.S. Origin,” International Legal Materials 16, no. 5 (September 1977): 1017-20.

28 "Agreement for Cooperation Between the Government of the United States of America and the Government of Japan Concerning Peaceful Uses of Nuclear Energy," November 1987.

${ }^{29}$ Suzuki, “The Fast Reactor and Its Fuel Cycle Developments in Japan," 70.
} 
both chemically volatile and intensely radioactive. ${ }^{30}$ By 2005 , the JAEC long-term plan pushed the expected start date for the commercialization of FBRs to beyond 2045, and in December 2016, the Japanese government decided to scrap its existing Monju prototype FBR, casting doubt on whether the commercialization of FBRs would ever occur. ${ }^{31}$

The pursuit of a higher degree of energy independence combined with the assumption that FBRs would soon become economically feasible to form the foundations for the institutionalization of closed fuel cycle technologies into Japan's nuclear industry. To this day, Japan maintains the policy of ultimately developing a closed fuel cycle for its nuclear industry. ${ }^{32}$ This process of institutionalization is not limited to national policy, however. The development of a closed fuel cycle has also become institutionalized in a series of laws, financial arrangements, political agreements, and even from the technical challenges of handling radioactive waste.

The 1957 Act on the Regulation of Nuclear Source Material, Nuclear Fuel Material, and Reactors required power plant operators to designate a spent fuel disposal method when submitting applications to build new nuclear power plants. ${ }^{33}$ Additionally, applications for the construction of nuclear power plants were required to conform to the Japanese government's long-term plans for nuclear power. ${ }^{34}$ These legal constraints meant that Japanese nuclear power plant operators were both required to develop reprocessing capabilities and also discouraged

\footnotetext{
${ }^{30}$ von Hippel, "Overview: The Rise and Fall of Plutonium Breeder Reactors," 6-10.

${ }^{31}$ Takubo and von Hippel, "Ending Reprocessing in Japan," 9; "Monju Prototype Reactor, Once a Key Cog in Japan's Nuclear Energy Policy, to Be Scrapped,” The Japan Times, December 21, 2016.

32 Japan Atomic Energy Commission, "Genshiryoku riyō ni kansuru kihon-teki kangaekata (an) [Basic Plan on the Use of Nuclear Power (Draft)],” April 26, 2017, http://www.aec.go.jp/jicst/NC/iinkai/teirei/siryo2017/siryo18/siryo1-1.pdf.

33 "Act on the Regulation of Nuclear Source Material, Nuclear Fuel Material, and Reactors (Act No. 116 of June 10, 1957)" (Japanese Law Translation, Ministry of Justice), http://www.japaneselawtranslation.go.jp/law/detail/?id=1941\&vm=04\&re=02.

34 The law specifically notes that, "approval of the application will not hinder the planned development and utilization of nuclear energy.” Ibid,; Takubo and von Hippel, “Ending Reprocessing in Japan,” 6.
} 
from exploring long-term spent fuel disposal methods. From the very start of operations of Japan's first nuclear power reactors in the 1970s, all of Japan's nuclear power plants were constructed with the assumption that spent fuel would be sent off site for reprocessing.

The decision to reprocess spent fuel also resulted in the establishment of political agreements between nuclear power plant operators and local communities. The Japanese government, with a keen interest in promoting nuclear power, played an important role in shaping the development of Japan's nuclear industry by providing funding for studies on where to locate power plants. As Daniel Aldrich notes, the locations of these power plants were not determined solely on technical merits (including seismic stability, access to cooling water, and distance from population centers), but also the inability for local communities to mount sustained opposition to the construction of plants. ${ }^{35}$ Many of these local communities were coopted into supporting nuclear power through education programs extoling the virtues of nuclear power, financial and economic incentives, and offers of employment at nuclear power plants. These local communities were also granted important influence in the operation of these plants: many agreements between power plant operators and local communities included the provision that local consent was required in order to make any modifications to nuclear facilities. ${ }^{36}$ This provision has further underscored the need to pursue reprocessing because local communities which originally agreed to host power plants under the condition that they would not become storage areas for nuclear waste - can object to the construction of on-site interim spent fuel storage methods like dry cask storage at local facilities. ${ }^{37}$

\footnotetext{
${ }^{35}$ Daniel P. Aldrich, Site Fights: Divisive Facilities and Civil Society in Japan and the West (Ithaca: Cornell University Press, 2008), ch 5.

${ }^{36}$ Takubo, "Wake Up, Stop Dreaming," 76.

37 Acton, "Wagging the Plutonium Dog," 17.
} 
With limited storage space available in the spent fuel pools at Japanese nuclear power plants, local opposition to on-site dry cask interim storage, and inadequate exploration of longterm nuclear waste disposal, reprocessing has become Japan's de facto policy for managing spent fuel. In 2006, two experts on Japan's nuclear industry warned that unless the Rokkasho Reprocessing Plant became operational, Japan would run out of spent fuel storage space by the mid-2020s and nuclear reactors would need to be shut down. ${ }^{38}$ This urgent need for storage space was only mitigated by the shutdown of reactors following the Fukushima Daiichi meltdown. However, it is worth noting that even if the Rokkasho Reprocessing Plant became operational, it would not necessarily solve Japan's spent fuel storage problem - it would simply shift the problem to a different stage of the fuel cycle. The radioactive byproducts from reprocessing would still require long-term storage, and with a very limited quantity of reprocessed material actually being used as intended in nuclear reactors, most of the separated plutonium would also remain in storage with no foreseeable use.

The local politics surrounding the Rokkasho Reprocessing Plant also influence Japan’s decision to continue pursuing nuclear reprocessing. The Rokkasho Reprocessing Plant is part of a larger complex that is slated to include uranium enrichment plants, MOX fuel fabrication facilities, and storage facilities for separated fissile material and the radioactive byproducts of reprocessing. These facilities are located at Rokkasho Village in Aomori Prefecture, which has long been one of the least economically developed areas of Japan. Per capita income in Aomori Prefecture is less than 80 percent that of the national average, and only 60 percent of Tokyo's. ${ }^{39}$ As a result, Rokkasho Village is heavily dependent on the nuclear complex as a source of jobs

\footnotetext{
${ }^{38}$ Tadahiro Katsuta and Tatsujiro Suzuki, "Japan's Spent Fuel and Plutonium Management Challenges" (International Panel on Fissile Materials, September 2006).

39 "Japan Statistical Yearbook 2017" (Statistics Bureau, Ministry of International Affairs and Communications, 2017), http://www.stat.go.jp/english/data/nenkan/66nenkan/index.htm.
} 
and revenue. This revenue includes subsidies for hosting nuclear facilities and taxes levied on nuclear activities. To date, these activities have brought in over 2.8 trillion yen to the prefecture and almost half of all Rokkasho Village inhabitants are employed in jobs related to the nuclear facilities. ${ }^{40}$ These economic incentives increase support among local communities and government officials for the continuation of Japan's nuclear reprocessing program, with Rokkasho Village being one of the most vocal proponents of reprocessing.

This support for Japan's reprocessing program is also motivated by local opposition to having Rokkasho Village become the site for permanent nuclear waste disposal. Although the Tokyo government promised Aomori Prefecture in 1994 that high-level waste would not be stored in the prefecture for more than fifty years, with over three thousand tons of spent fuel stored at Rokkasho, there are concerns that the village would continue to be used as a storage site for nuclear materials even if reprocessing were abandoned ${ }^{41}$ However, local politicians in Aomori and Rokkasho are not without leverage. In the 1970s and 1980s, Japan signed agreements with France and the United Kingdom to have spent fuel shipped abroad to be reprocessed. The separated fissile material and related waste would then be sent back to Japan through a port in Aomori Prefecture, where it would be held at Rokkasho. The central role that Aomori plays in the management of nuclear materials provides it with veto power over the national government: The Aomori government could threaten to either block the shipments of nuclear materials from abroad, causing Japan to renege on its agreements with France and the United Kingdom, or it could demand the removal of spent fuel from Rokkasho, undermining the

\footnotetext{
${ }^{40}$ Todd Crowell, "Why Japan's Rokkasho Nuclear Reprocessing Plant Lives On,” The Diplomat, April 18, 2016.

${ }^{41}$ Acton, "Wagging the Plutonium Dog," 10.
} 
agreement between power plant operators and local communities around Japan not to store spent fuel at local power plants. ${ }^{42}$

A policy that was meant to achieve a higher degree of energy independence became institutionalized into a complex set of legal requirements, political commitments, and financial arrangements reinforcing the use of reprocessing as a de facto spent fuel management solution.

The Japanese government no longer continues the development of a closed fuel cycle as a way to achieve energy security, but instead as a way to satisfy the veto players that support a continuation of reprocessing for their own interests.

The institutionalized pressures to continue reprocessing have been intense. The Fukushima Daiichi nuclear meltdown following the March 11, 2011 earthquake and tsunami served as a massive shock to the Japanese nuclear industry. Public opinion not only turned against nuclear power, but against the "nuclear village" of industry members, government bureaucrats, and academics that reportedly failed to adequately and transparently assess the risks of nuclear power. ${ }^{43}$ However, even this public pressure was not enough to end reprocessing. Shortly after the March 11, 2011 disasters, the Noda Yoshihiko Administration formed the Energy and Environment Council (EEC) to review Japan's nuclear energy policies. The JAEC, advising the EEC, argued that if Japan were to phase out nuclear power it should also abandon nuclear reprocessing. ${ }^{44}$ Facing widespread public opposition to nuclear power, the EEC and Noda Administration carefully weighed their options before concluding that they would abandon nuclear power but would continue with reprocessing. In explaining the decision to continue reprocessing, the EEC did not cite energy security as a justification. Instead, it merely referred to

\footnotetext{
${ }^{42}$ Ibid., 9-12.

${ }^{43}$ Richard J. Samuels, 3.11: Disaster and Change in Japan (Ithaca: Cornell University Press, 2013), 118-22.

${ }^{44}$ Acton, "Wagging the Plutonium Dog," 13.
} 
the need to uphold the Japanese government's commitments to Aomori Prefecture. ${ }^{45}$ Neither the changing international energy environment, nor domestic opposition to nuclear power could overcome the institutional pressures driving reprocessing.

\section{The Nuclear Hedge}

Developing in parallel with Japan's nuclear industry was Japan's policy of nuclear hedging: Japan would refrain from developing nuclear weapons, rely on the U.S. nuclear umbrella, and abide by strict nonproliferation norms and safeguards - but would also maintain the constitutional prerogative and technical potential to develop nuclear weapons. Policymakers have maintained the constitutionality of acquiring nuclear weapons since Prime Minister Kishi Nobusuke's statement in 1957 that the possession of "defensive" nuclear weapons would not violate Article Nine of the Japanese constitution. ${ }^{46}$ Over the decades, the government has also sanctioned studies exploring the possibility of nuclear armament. However, these studies have consistently found that even though Japan possesses the technologies necessary to develop nuclear weapons within a relatively short timeframe, it would not be in Japan's strategic interest to do so. In each case, Japan has resoundingly rejected the prospect of nuclear armament in favor of relying on U.S. extended deterrence.

The goal of maintaining a latent nuclear weapons capability - much like the pursuit of a closed fuel cycle - was initially driven by external factors. In the 1950s and 1960s, consecutive

\footnotetext{
45 The Energy and Environment Council, Government of Japan, "Innovative Strategy for Energy and the Environment," September 14, 2012.

${ }^{46}$ Prime Minister Kishi's statement followed Defense Agency Chief Kodaki Akira's similar statement on April 25, 1957 that the Japan Defense Agency could have "nuclear weapons to the minimum extent necessary for the sake of defense." "Jiei-ken han'inara kakuheiki hoyū mo ka [Nuclear Weapons Also Permissible Under Self Defense]," Asahi Shimbun, May 7, 1957; "Telegram from the Embassy in Japan to the Department of State," in Foreign Relations of the United States 1955-1957, vol. XXIII Part 1, Japan (Washington, D.C.: Government Printing Office), Document 132.
} 
Prime Ministers Kishi Nobusuke, Ikeda Hayato, and Satō Eisaku all considered the development of nuclear weapons as a way for Japan to guarantee its security and autonomy. At a time when geopolitical tensions in East Asia were rising, Japan remained relatively weak; Japan was still recovering from World War II while the rest of Asia became engrossed in Cold War tensions. Nuclear weapons were therefore seen as a potentially cost effective way for Japan to meet its security interests.

Prime Minister Kishi was an ardent supporter of Japanese remilitarization in the postwar years, never having fully abandoned Imperial Japan's quest for autonomy. As noted previously, he set the precedent in 1957 of interpreting the constitution in a way that allowed for the possession of tactical nuclear weapons for self-defense. Visiting the recently established Tokaimura Atomic Research Institute in 1958, Kishi lent credence to the notion of maintaining a latent nuclear weapons capability as a hedge against international instability, observing that "even without nuclear weapons, Japan would have a stronger say in the international arena - as in arms control and nuclear test-ban issues - by improving its nuclear latency potential. ${ }^{, 47}$ Prime Minister Ikeda Hayato, best known for his so-called "income doubling plan," held similar views, noting Japan's perceived lack of status in the international community due to its dependence on the United States for security. ${ }^{48}$

An important but often overlooked fact when examining Kishi and Ikeda's considerations of nuclear weapons is the different strategic environment facing these early postwar prime ministers; specifically, the fact that the U.S. nuclear umbrella was not explicitly extended to Japan until 1965. The initial 1952 U.S.-Japan security treaty did not include a binding commitment by the United States to defend Japan, stating instead that "[U.S. forces in Japan]

\footnotetext{
${ }^{47}$ Taka Daitoku, “The Construction of a Virtual Nuclear State: Japan's Realistic Approach to an Emerging Nuclear Nonproliferation Regime, 1964-1970,” October 2014, 11.

${ }^{48}$ Ibid., 13-14.
} 
may be utilized to contribute to the maintenance of international peace and security in the Far East and to the security of Japan against armed attack" (emphasis added). Japanese criticisms of the one-sided nature of the alliance and U.S. concerns that Japan would adopt a position of neutrality in the Cold War led to the 1960 revision of the U.S.-Japan security treaty. ${ }^{49}$ Although the revised 1960 treaty included the now-standard Article Five that established the United States' commitment to defend Japan, there were still doubts about whether that commitment extended to the use of the nuclear weapons. For example, in a meeting of the Joint U.S.-Japan Committee on Trade and Economic Affairs in December 1962, Secretary of State Dean Rusk urged his Japanese counterparts to strengthen Japan's defense capabilities, explaining that because the Soviet Union possessed nuclear weapons, "a nuclear exchange is not a defense operation [the United States] would want to undertake." ${ }^{50}$ It was not until 1965 that the United States formally extended the nuclear umbrella to Japan. This explicit security guarantee, which Japan received during Prime Minister Satō Eisaku’s administration, became one of the most important and enduring elements of Japan's hedging strategy.

After China’s first nuclear test in October 1964, Prime Minister Satō sought assurances from the United States that it would use nuclear weapons to defend Japan if attacked. To do so, Satō first hinted at the possibility that Japan could acquire its own nuclear arsenal. Meeting with Ambassador Edwin Reischauer in December 1964, Satō noted that "it was only common sense" for Japan to have nuclear weapons if other states possessed them as well. ${ }^{51}$ Furthermore, Satō noted that Japan had the scientific and industrial capability to develop nuclear weapons if it

\footnotetext{
49 "Letter from the Ambassador to Japan (MacArthur) to Secretary of State Dulles," in Foreign Relations of the United States 1958-1960, vol. XVIII, Japan; Korea (Washington, D.C.: Government Printing Office), Document 11; "Telegram from the Embassy in Japan to the Department of State," in Foreign Relations of the United States 19581960, vol. XVIII, Japan; Korea (Washington, D.C.: Government Printing Office), Document 20.

50 "Memorandum of Conversation," in Foreign Relations of the United States 1961-1963, vol. XXII, Northeast Asia (Washington, D.C.: Government Printing Office), Document 362.

51 "Telegram from the Embassy in Japan to the Department of State," in Foreign Relations of the United States 1964-1968, vol. XXIX Part 2, Japan (Washington, D.C.: Government Printing Office), Document 37.
} 
chose to do so. This exchange reportedly alarmed Reischauer and prompted him to advise Secretary of State Dean Rusk to extend the nuclear umbrella to Japan. ${ }^{52}$ Two weeks later on January 12, 1965, when Satō met with President Lyndon Johnson, he received confirmation that the United States extended its nuclear deterrent to Japan. ${ }^{53}$ The U.S. nuclear guarantee was reiterated publicly the next day in a Johnson-Satō joint statement, in which the United States expressed its commitment to "defend Japan against any armed attack" - a commitment interpreted as covering both conventional and nuclear attack. ${ }^{54}$ The critical link between Japan's nuclear weapons potential and the credibility of the U.S. nuclear umbrella soon became clear. As early as 1968, U.S. government officials acknowledged that the maintenance of a credible nuclear deterrent was a key factor in determining whether Japan acquired nuclear weapons. ${ }^{55}$

During the Cold War, Japan also maintained a confidential agreement with the United States to allow for the transit of nuclear weapons through Japanese waters and ports, while prohibiting their introduction onto Japanese soil. This agreement centered on the ambiguity surrounding the meaning of "introducing" nuclear weapons into Japan. The United States and Japan privately agreed that the prohibition on introducing nuclear weapons did not include the "transit" of these weapons. This intentional linguistic ambiguity allowed Japanese politicians to tacitly accept the transit of nuclear-armed ships through Japanese waters and ports while still

\footnotetext{
${ }_{53}^{52}$ Yukinori Komine, Negotiating the U.S.-Japan Alliance: Japan Confidential (New York: Routledge, 2017), 47. 53 "Memorandum of Conversation," in Foreign Relations of the United States 1964-1968, vol. XXIX Part 2, Japan (Washington, D.C.: Government Printing Office), Document 41. Prime Minister Satō received similar assurances on January 13, when he met with Defense Secretary McNamara. "Nitchū-sen katei 'kaku hōfuku o' 65-nen hōbei-ji no satō shushō, amerika ni hyōmei [In 1965 Visit to United States, Prime Minister Satō Seeks Commitment of 'Nuclear Retaliation' from the United States in the Event of a Japan-China Conflict]," Asahi Shimbun, December 22, 2008.

${ }^{54}$ Lyndon B. Johnson, "Joint Statement Following Meetings with the Prime Minister of Japan." (The American Presidency Project, January 13, 1965), http://www.presidency.ucsb.edu/ws/?pid=26852.

55 "Intelligence Note from the Director of the Bureau of Intelligence and Research (Hughes) to Secretary Rusk," in Foreign Relations of the United States 1964-1968, vol. XXIX Part 2, Japan (Washington, D.C.: Government Printing Office), Document 113.
} 
being able to publicly deny the "introduction" of nuclear weapons into Japan. ${ }^{56}$ In this way, the Japanese policy of maintaining the credibility of the U.S. nuclear umbrella during the Cold War followed a "carrot and stick" approach: Japan aided U.S. nuclear force projection in the region, while also implicitly threatening to acquire nuclear weapons if necessary. This marked a notable, but subtle shift in Japan's hedging strategy: Japan did not need a specific breakout plan to build a nuclear weapon; it merely needed the general technological foundations to do so. This baseline latent nuclear weapons capability was already provided by Japan's growing civilian nuclear industry. Moreover, the ultimate guarantor of Japan's security would not be Japan's own latent nuclear weapons capability itself, but instead the nuclear weapons of the United States. Beginning with the first National Defense Program Outline in 1976, all subsequent outlines have explicitly stated that Japan would rely on the U.S. nuclear umbrella for deterrence. ${ }^{57}$ As the U.S. nuclear umbrella and pattern of reassurances became institutionalized into the alliance, so too did Japan's policy of nuclear hedging.

Over the years, the Japanese government has periodically conducted and commissioned studies to assess the technical feasibility and strategic implications of developing nuclear weapons. One example is the "Basic Studies of Japan's Nuclear Policy" (often referred to in English as the 1968/1970 Report), which was conducted beginning in 1967 by a group of four non-governmental nuclear and political science academics at the request of the Satō Administration's Cabinet Information Research Office. ${ }^{58}$ This study was a comprehensive examination of the costs and benefits of developing nuclear weapons. From a technical

\footnotetext{
${ }^{56}$ Komine, Negotiating the U.S.-Japan Alliance, 35-38.

57 Japan Defense Agency, "National Defense Program Outline for 1976"; Japan Defense Agency, "National Defense Program Outline in and after FY 1996"; Japan Defense Agency, "National Defense Program Guidelines, FY 2005"; Japan Ministry of Defense, "National Defense Program Guidelines for FY 2011 and Beyond"; and Japan Ministry of Defense, "National Defense Program Guidelines for FY 2014 and Beyond."

${ }^{58}$ Daitoku, "The Construction of a Virtual Nuclear State," 31-32.
} 
perspective, the report concluded that Japan could possess the technologies necessary for a minimal nuclear arsenal within ten years. ${ }^{59}$ However, the report also noted that there would be significant political obstacles to overcome in order to develop nuclear weapons - and most importantly, that Japan possessing nuclear weapons made little strategic sense. Due to Japan's geography and the concentration of population and industrial centers in small areas, Japan would be incredibly vulnerable to a nuclear counterstrike. The report also noted the likelihood that Japan acquiring nuclear weapons would dramatically worsen its relations with neighboring states and ultimately decrease Japan's security. ${ }^{60}$ The conclusions drawn from this report have been maintained through successive administrations. A 1995 Japan Defense Agency study examining Japan's nuclear option in the aftermath of the 1994 North Korean nuclear crisis reiterated the same conclusion that while Japan had the capability to acquire nuclear weapons, there were significant costs and little strategic benefits in doing so. ${ }^{61}$

To further institutionalize Japan's non-nuclear choice, Japan has submitted to stringent international nonproliferation norms and regimes. Japan was one of the first states to join the IAEA in 1957, and in 1959 it concluded one of the agency's first safeguards agreements for the transfer of uranium. ${ }^{62}$ Upon signing the Treaty on the Non-Proliferation of Nuclear Weapons in 1976, Japan and the IAEA concluded another agreement on more comprehensive safeguards covering all fissile material within Japan to ensure its peaceful use. ${ }^{63}$ Since then, Japan has

\footnotetext{
59 “'Kaku busō kanōdaga motenu' Satō naikaku ga 68, 70-nen ni himitsu kenkyū hōkoku-sho [ 'Nuclear arms possible, but won't be obtained' Satō Cabinet's secret report in 1960 and 1970]," Asahi Shimbun, November 13, 1994.

60 "Nihon no kaku seisaku ni kansuru kiso-teki kenkyū <yōshi> [Basic Studies of Japan's Nuclear Policy (Summary)]," Asahi Shimbun, November 13, 1994.

61 "Kaku busō kenkyū hōkoku-sho <yōshi> [Nuclear Arms Research Report]," Asahi Shimbun, February 20, 2003.

62 "The Texts of Instruments Connected with the Agency's Supply of Uranium to Japan," INFCIRC/3 (International Atomic Energy Agency, April 15, 1959).

63 "The Text of the Agreement of 4 March 1977 between Japan and the International Atomic Energy Agency in Implementation of Article III 1 and 4 of the Treaty on the Non-Proliferation of Nuclear Weapons," INFCIRC/255 (International Atomic Energy Agency, March 1978).
} 
contributed to the development of safeguard technologies through the Japan Support Programme for Agency Safeguards (JASPAS) and has become the world's largest recipient of on-site IAEA verification. Japan has also cooperated closely with the IAEA to develop and implement built-in safeguards at the Rokkasho Reprocessing Plant to accurately account for nuclear materials throughout the separation process. ${ }^{64}$ Finally, although somewhat ironic considering Japan's dependence on the U.S. nuclear umbrella, Japan has also maintained a firm commitment to global disarmament through various multilateral initiatives and organizations. ${ }^{65}$

Japan's nuclear hedge serves a purpose beyond providing Japan with a nuclear weapons capability as a last resort in a severe security crisis; it also plays an active role in shaping the strategic landscape of Northeast Asia. At the core of Japan's nuclear hedge is the calculus that although Japan theoretically possesses the capability to develop nuclear weapons, under the current security situation it has no intention of doing so. ${ }^{66}$ The most important variable in Japan's calculus has been the U.S. security guarantee and the willingness of the United States to defend Japan vis-à-vis any potential adversaries. In recent decades, policymakers both inside and outside Japan have cited the prospect of a nuclear-armed Japan as a potential consequence of the shifting strategic environment in Northeast Asia.

As China's military and economic strength grew and tensions with Japan increased following the end of the Cold War, many prominent Japanese policymakers drew attention to Japan's nuclear option. In 2002, Ozawa Ichirō, a former Liberal Democratic Party member and then-member of the opposition Liberal Party, cautioned that China's military buildup could

\footnotetext{
64 "Safeguards Activities in Japan” (Tokyo: The Nuclear Regulation Authority, October 17, 2016).

${ }^{65}$ Yuki Tatsumi and Robert Weiner, "Political Influence on Japanese Nuclear and Security Policy: New Forces Face Large Obstacles” (Monterey: U.S. Navy Postgraduate School, February 2014), 16-18.

${ }^{66}$ Alexandre Debs and Nuno P. Monteiro present a formal model of this calculus, although they utilize the terms "willingness" and "opportunity" as the key variables determining when a state will proliferate. See: Debs and Monteiro, Nuclear Politics, ch 2.
} 
cause "hysteria" among the Japanese public and that "developing nuclear weapons would be easy" using Japan's stockpile of separated plutonium. ${ }^{67}$ Additionally, then-Deputy Chief Cabinet Secretary Abe Shinzō and then-Chief Cabinet Secretary Fukuda Yasuo both reiterated the constitutionality and legality of Japan possessing nuclear weapons. ${ }^{68}$ Similarly, as North Korea's nuclear program advanced towards its first nuclear test in 2006, several high-ranking U.S. government officials warned of Japan's capability to acquire nuclear weapons as a way to pressure China into taking a stronger position against North Korea. ${ }^{69}$

Over a decade later, North Korea has detonated a total of six nuclear devices, and in July 2017, the regime tested an intercontinental ballistic missile (ICBM) theoretically capable of striking the mainland United States. This capability has raised fears of "decoupling" in the U.S.Japan alliance - or, to paraphrase Charles de Gaulle's famous question, whether Washington would trade Los Angeles for Tokyo. If North Korea has the capability to strike the United States with nuclear weapons, then the United States may be deterred from coming to the defense of its allies during a conflict. In the months after North Korea's ICBM test, policymakers in both South Korea and Japan have considered the possibility of reintroducing U.S. tactical nuclear weapons to enhance deterrence. ${ }^{70}$ As the security environment in Northeast Asia worsens, the United States faces pressures to maintain strategic stability not only to deter North Korea, but to dissuade allies - including Japan and South Korea - from pursuing the nuclear option.

\footnotetext{
67 “Jiyūtō ozawa ichirō-shi 'kaku busō wa kantan’ chūgoku-gawa ni gunbi zōkyō o kensei [Liberal Party’s Ozawa Ichirō, 'Nuclear Weapons Are Easy,' Urges Restraint in Chinese Military Buildup],' Asahi Shimbun, April 7, 2002. ${ }^{68}$ Campbell and Sunohara, "Japan: Thinking the Unthinkable," 229.

${ }^{69}$ These policymakers include: Undersecretary of State for Arms Control and International Security John Bolton, Vice President Richard Cheney, Senator John McCain, and former Secretary of Defense William Perry. Ibid., 238.

${ }^{70}$ Tim Kelly and Nobuhiro Kubo, "Allowing Nuclear Weapons in Japan Could Defuse North Korean Threat, Say Some Policy Makers," Reuters, September 6, 2017; Anna Fifield, "South Korea's Defense Minister Suggests Bringing Back Tactical U.S. Nuclear Weapons,” The Washington Post, September 4, 2017.
} 
Institutions, Interests, and Stakeholders

The development of Japan's nuclear policies was strongly influenced by external factors. However, over time these policies have become institutionalized into Japan's nuclear industry and security strategy to serve different purposes than originally intended. Today, Japan's reprocessing program plays an important role in managing spent fuel and meeting the demands of key veto players in Japan's nuclear industry, and Japan's nuclear hedge plays an active role in shaping the regional strategic environment and emphasizing the importance of maintaining the credibility of U.S. extended deterrence. When outlining the pressures and constraints that perpetuate Japan's nuclear policies, it is also important to hypothesize what changes might lead to a fundamental shift in these institutionalized policy outcomes. This requires identifying the key interests and stakeholders that are served by these policies.

Japan's continued pursuit of a closed fuel cycle is driven mainly by the local and regional politics surrounding the issue of managing spent fuel. Put simply, few locales want to host radioactive waste for decades, if not hundreds of years. Local communities across Japan agreed to host nuclear power plants on the condition that spent fuel would not be stored on site, and similarly, a promise was made to Aomori Prefecture that it would not host nuclear waste for long-term storage. Although an alternative method of spent fuel management such as permanent underground disposal offers a way to satisfy the interests of veto players in the nuclear industry, these efforts have made little progress. On July 28, 2017, the Ministry of Economy, Trade, and Industry released a preliminary map identifying locations that on geographic and scientific grounds could be suitable disposal sites. However, Minister Sekō Hiroshige noted that the map was only a "first step on a long road," and the government may take up to twenty years to select 
a disposal site. ${ }^{71}$ A wholesale abandonment of nuclear power in Japan would likely bring an end to Japan's closed fuel cycle ambitions, but this prospect is also unlikely to happen in the near future. Although large portions of the Japanese public oppose nuclear power, the current government has taken a more pragmatic approach, recognizing that nuclear power is essential to meeting Japan's energy needs in the near-term. Japanese policymakers also face pressures from the United States to continue the use of nuclear power. U.S. experts have cited close cooperation between U.S. and Japanese nuclear industries, the need to reduce carbon emissions, and U.S.Japan leadership in ensuring the safe use of nuclear power worldwide as reasons why Japan should not abandon nuclear power. ${ }^{72}$

While Japan's continued development of a closed fuel cycle is driven primarily by domestic politics, Japan's nuclear hedge is influenced primarily by external factors and the extent to which Japan believes that it can remain secure while foregoing nuclear weapons. One of the most important variables in Japan's strategic calculus is the credibility of U.S. extended deterrence. An outright failure to defend Japan poses the greatest threat to the U.S.-Japan alliance and Japan's non-nuclear choice, but more subtle shifts in perceptions of extended deterrence and the United States' ability to defend Japan also play an important role. Additionally, if other U.S. allies such as South Korea were to acquire nuclear weapons capabilities in response to heightened tensions in Northeast Asia, Japan too may feel pressures to revisit the nuclear option to avoid remaining the only non-nuclear state in the region.

Because the policies of reprocessing as a spent fuel management solution and nuclear hedging were institutionalized separately, they are perpetuated by different pressures and

\footnotetext{
71 “Japan Map Shows Possible Permanent Sites for Nuclear Waste,” Nikkei Asian Review, July 28, 2017.

72 Michael J. Green, "Michael Green: Japan's Nuclear Dilemma One Year after 3-11,” Forum on Energy, February 26, 2012; Kazuaki Nagata, "Japan's Adherence to Nuclear Power Critical at Home and Overseas: MIT Luminary," The Japan Times, February 21, 2015.
} 
constraints. As a result, the extent to which Japan develops closed fuel cycle technologies today is not indicative of Japan's intention to develop nuclear weapons, and conversely, Japan's policy of nuclear hedging is not the primary driver behind the structure of Japan's nuclear industry. The credibility of the U.S. nuclear umbrella is the key variable in Japan's non-nuclear choice, but it has little, if any, impact on Japan's continued pursuit of reprocessing.

\section{Conclusion}

The framework of dynamic institutionalization provides a comprehensive explanation for Japan's nuclear policies. Japanese policymakers have maintained a keen awareness of Japan's position in the international system in their pursuit of security and prosperity. This strategic culture led Japanese policymakers to initially pursue closed fuel cycle technologies as a way to promote energy independence and maintain a latent nuclear weapons capability. However, over time this has resulted in two separate sets of institutionalized policies: The continued pursuit of reprocessing as a de facto spent fuel management solution, and Japan's nuclear hedge, which emphasizes the critical importance of the U.S. nuclear umbrella to Japan's security and nonnuclear choice.

This argument has a number of important policy implications for the United States as it manages its relationship with Japan and seeks to uphold the global nonproliferation regime. The first implication is that although the United States has a clear interest in encouraging Japan to end its reprocessing program due to the security and proliferation concerns it raises, no amount of reassurance in the U.S. nuclear umbrella will convince Japan to do so. In order for Japan to 
abandon reprocessing and its greater vision of implementing a closed fuel cycle, it will need to first address the underlying institutionalized constraints that have perpetuated this pursuit.

The second implication is a logical extension of the first: The continuation of Japan's reprocessing program does not indicate a lack of trust in U.S. extended nuclear deterrence. While policymakers have indeed frequently cited Japan's technical and constitutional ability to develop nuclear weapons, they have repeatedly and resoundingly rejected nuclear armament in favor of continued reliance on the U.S. nuclear umbrella. At the moment, concerns of an impending nuclear arms race in Northeast Asia are unfounded.

Finally, as geopolitical tensions rise in Northeast Asia due to a rising China and belligerent North Korea, the United States will need to carefully calibrate its own conventional and nuclear posture in the region to ensure that its allies continue to choose nuclear forbearance over proliferation. The U.S. alliance network in Asia has itself followed the process of dynamic institutionalization. Originally established as a way to contain communism during the Cold War, the alliance network persists today in an increasingly complex multipolar environment with a broader range of interests, stakeholders, and threats. Adapting these decades-old institutions to a post-Cold War era will be an important challenge for the Unites States in the coming years.

In 2018, the U.S.-Japan Section 123 Agreement - which grants Japan the right to reprocess spent fuel - is set for automatic renewal unless either side makes a request for renegotiation. That same year, Japan plans to begin operating the Rokkasho Reprocessing Plant. These two events, combined with overall rising tensions in East Asia, have drawn increasing attention from observers and policymakers alike to Japan's reprocessing program. This moment provides an important opportunity for the United States and Japan to take on this issue to strengthen bilateral relations and the global nonproliferation regime. However, doing so will 
require a complete understanding of this complex issue. The framework of dynamic institutionalization presented here presents an alternative to the current understanding of Japan's nuclear policies by incorporating domestic, international, and institutionalized variables, across time, to provide a comprehensive explanation of Japan's development of closed fuel cycle technologies and nuclear hedge. Solving Japan's radioactive problem will not be easy, but developing a more complete understanding of the issue is a critical first step. 


\section{Bibliography}

"Act on the Regulation of Nuclear Source Material, Nuclear Fuel Material, and Reactors (Act No. 116 of June 10, 1957).” Japanese Law Translation, Ministry of Justice. http://www.japaneselawtranslation.go.jp/law/detail/?id=1941\&vm=04\&re $=02$.

Acton, James M. "Wagging the Plutonium Dog: Japanese Domestic Politics and Its International Security Implications." Washington D.C.: The Carnegie Endowment for International Peace, 2015.

"Agreement for Cooperation Between the Government of the United States of America and the Government of Japan Concerning Peaceful Uses of Nuclear Energy,” November 1987.

Aldrich, Daniel P. Site Fights: Divisive Facilities and Civil Society in Japan and the West. Ithaca: Cornell University Press, 2008.

Art, Robert J. "The United States and the Rise of China: Implications for the Long Haul." Political Science Quarterly 125, no. 3 (Fall 2010): 359-91.

“Atomic Energy Basic Act (Act No. 186 of December 19, 1955).” Japanese Law Translation, Ministry of Justice. http://www.japaneselawtranslation.go.jp/law/detail/?id=2233\&vm=04\&re=02.

Berger, Thomas U. Cultures of Antimilitarism: National Security in Germany and Japan. Baltimore: Johns Hopkins University Press, 1998.

Bunn, Matthew, Steve Fetter, John P. Holdren, and Bob van der Zwaan. "The Economics of Reprocessing vs. Direct Disposal of Spent Nuclear Fuel." Cambridge: Project on Managing the Atom, Belfer Center for Science and International Affairs, 2003.

Campbell, Kurt M., and Tsuyoshi Sunohara. "Japan: Thinking the Unthinkable." In The Nuclear Tipping Point: Why States Reconsider Their Nuclear Choices, edited by Kurt M. Campbell, Robert J. Einhorn, and Mitchell Reiss, 218-53. Washington, D.C.: Brookings Institution Press, 2004.

Cha, Victor D. Powerplay: The Origins of the American Alliance System in Asia. Princeton: Princeton University Press, 2016.

Crowell, Todd. "Why Japan's Rokkasho Nuclear Reprocessing Plant Lives On.” The Diplomat, April 18, 2016.

Daitoku, Taka. "The Construction of a Virtual Nuclear State: Japan's Realistic Approach to an Emerging Nuclear Nonproliferation Regime, 1964-1970,” October 2014.

Debs, Alexandre, and Nuno P. Monteiro. Nuclear Politics: The Strategic Causes of Proliferation. New York: Cambridge University Press, 2017. 
“Energy Policies of IEA Countries: Japan.” Paris: International Energy Agency, 2016.

Fifield, Anna. “South Korea's Defense Minister Suggests Bringing Back Tactical U.S. Nuclear Weapons." The Washington Post, September 4, 2017.

"Genshiryoku no kenkyū, kaihatsu oyobi riyō ni kansuru chōki keikaku [Long Term Plan on Nuclear Research, Development, and Use].” Japan Atomic Energy Commission, 1956. http://www.aec.go.jp/jicst/NC/tyoki/tyoki1956/chokei.htm.

Green, Michael J. "Michael Green: Japan's Nuclear Dilemma One Year after 3-11.” Forum on Energy, February 26, 2012.

Holmes, James R., and Toshi Yoshihara. "Thinking About the Unthinkable: Tokyo's Nuclear Option." In Strategy in the Second Nuclear Age: Power, Ambition, and the Ultimate Weapon, edited by Toshi Yoshihara and James R. Holmes, 115-32. Washington, D.C.: Georgetown University Press, 2012.

"Intelligence Note from the Director of the Bureau of Intelligence and Research (Hughes) to Secretary Rusk." In Foreign Relations of the United States 1964-1968, XXIX Part 2, Japan: Document 113. Washington, D.C.: Government Printing Office.

Japan Atomic Energy Commission. "Genshiryoku Riyō Ni Kansuru Kihon-Teki Kangaekata (an) [Basic Plan on the Use of Nuclear Power (Draft)]," April 26, 2017. http://www.aec.go.jp/jicst/NC/iinkai/teirei/siryo2017/siryo18/siryo1-1.pdf.

Japan Defense Agency. “National Defense Program Guidelines, FY 2005.”

—. "National Defense Program Outline for 1976."

—_. "National Defense Program Outline in and after FY 1996."

“Japan Map Shows Possible Permanent Sites for Nuclear Waste." Nikkei Asian Review, July 28, 2017.

Japan Ministry of Defense. "National Defense Program Guidelines for FY 2011 and Beyond."

—_. "National Defense Program Guidelines for FY 2014 and Beyond."

Japan Nuclear Fuel Limited. "Rokkasho Reprocessing Plant," 2014. http://www.jnfl.co.jp/en/about/publication/file/reprocessing_plant.pdf.

“Japan Statistical Yearbook 2017." Statistics Bureau, Ministry of International Affairs and Communications, 2017. http://www.stat.go.jp/english/data/nenkan/66nenkan/index.htm. 
"Japan-United States: Agreement on Reprocessing Nuclear Material of U.S. Origin." International Legal Materials 16, no. 5 (September 1977): 1017-20.

"Jiei-ken han'inara kakuheiki hoyū mo ka [Nuclear Weapons Also Permissible Under Self Defense]." Asahi Shimbun, May 7, 1957.

"Jiyūtō ozawa ichirō-shi 'kaku busō wa kantan' chūgoku-gawa ni gunbi zōkyō o kensei [Liberal Party's Ozawa Ichirō, 'Nuclear Weapons Are Easy,' Urges Restraint in Chinese Military Buildup].” Asahi Shimbun, April 7, 2002.

Johnson, Lyndon B. "Joint Statement Following Meetings With the Prime Minister of Japan." The American Presidency Project, January 13, 1965. http://www.presidency.ucsb.edu/ws/?pid=26852.

“'Kaku busō kanōdaga motenu’ Satō naikaku ga 68, 70-nen ni himitsu kenkyū hōkoku-sho ['Nuclear arms possible, but won't be obtained' Satō Cabinet's secret report in 1960 and 1970]." Asahi Shimbun, November 13, 1994.

"Kaku busō kenkyū hōkoku-sho <yōshi> [Nuclear Arms Research Report (Summary)]." Asahi Shimbun, February 20, 2003.

Kamiya, Matake. "Nuclear Japan: Oxymoron or Coming Soon?" The Washington Quarterly 26, no. 1 (December 2002): 63-75.

Katsuta, Tadahiro, and Tatsujiro Suzuki. "Japan's Spent Fuel and Plutonium Management Challenges." International Panel on Fissile Materials, September 2006.

Kelly, Tim, and Nobuhiro Kubo. "Allowing Nuclear Weapons in Japan Could Defuse North Korean Threat, Say Some Policy Makers.” Reuters, September 6, 2017.

Komine, Yukinori. Negotiating the U.S.-Japan Alliance: Japan Confidential. New York: Routledge, 2017.

"Letter from the Ambassador to Japan (MacArthur) to Secretary of State Dulles." In Foreign Relations of the United States 1958-1960, XVIII, Japan; Korea: Document 11. Washington, D.C.: Government Printing Office.

Mark, J. Carson, Frank von Hippel, and Edward Lyman. "Explosive Properties of Reactor-Grade Plutonium." Science \& Global Security 17, no. 2-3 (2009): 170-85.

Mearsheimer, John J. The Tragedy of Great Power Politics. Updated edition. New York: W.W. Norton \& Company, 2014.

"Memorandum of Conversation." In Foreign Relations of the United States 1961-1963, XXII, Northeast Asia: Document 362. Washington, D.C.: Government Printing Office. 
“Memorandum of Conversation." In Foreign Relations of the United States 1964-1968, XXIX Part 2, Japan: Document 41. Washington, D.C.: Government Printing Office.

"Monju Prototype Reactor, Once a Key Cog in Japan's Nuclear Energy Policy, to Be Scrapped." The Japan Times, December 21, 2016.

Moravcsik, Andrew. "Taking Preferences Seriously: A Liberal Theory of International Politics." International Organization 51, no. 4 (Autumn 1997): 513-53.

Nagata, Kazuaki. "Japan's Adherence to Nuclear Power Critical at Home and Overseas: MIT Luminary." The Japan Times, February 21, 2015.

Nester, William R. Japanese Industrial Targeting: The Neomercantilist Path to Economic Superpower. New York: St. Martin's Press, 1991.

"Nihon no kaku seisaku ni kansuru kiso-teki kenkyū <yōshi> [Basic Studies of Japan's Nuclear Policy (Summary)].” Asahi Shimbun, November 13, 1994.

“Nitchū-sen katei ‘kaku hōfuku o’ 65-nen hōbei-ji no satō shushō, amerika ni hyōmei [In 1965 Visit to United States, Prime Minister Satō Seeks Commitment of 'Nuclear Retaliation' from the United States in the Event of a Japan-China Conflict]." Asahi Shimbun, December 22, 2008.

Oros, Andrew. Normalizing Japan: Politics, Identity, and the Evolution of Security Practice. Stanford: Stanford University Press, 2008.

"Safeguards Activities in Japan.” Tokyo: The Nuclear Regulation Authority, October 17, 2016.

Samuels, Richard J. 3.11: Disaster and Change in Japan. Ithaca: Cornell University Press, 2013.

- Securing Japan: Tokyo's Grand Strategy and the Future of East Asia. Ithaca: Cornell University Press, 2008.

Samuels, Richard J., and James L. Schoff. "Japan's Nuclear Hedge: Beyond 'Allergy' and Breakout." In Asia in the Second Nuclear Age, edited by Ashley J. Tellis, 233-64. Seattle: National Bureau of Asian Research, 2013.

Schoff, James L. "Changing Perceptions of Extended Deterrence in Japan." In Strategy in the Second Nuclear Age: Power, Ambition, and the Ultimate Weapon, edited by Toshi Yoshihara and James R. Holmes, 99-113. Washington, D.C.: Georgetown University Press, 2012.

Self, Benjamin L., and Jeffrey W. Thompson, eds. Japan's Nuclear Option: Security, Politics, and Policy in the 21st Century. Washington, D.C.: The Henry L. Stimson Center, 2003.

Sokolski, Henry D. “A Plutonium-Rich Asia.” National Review, September 24, 2014. 
- Nuclear Weapons Material Gone Missing: What Does History Teach? Carlisle: U.S. Army War College Press, 2014.

Suzuki, Tatsujiro. "The Fast Reactor and Its Fuel Cycle Developments in Japan: Can Japan Unlock Its Development Path?" Science \& Global Security 17, no. 1 (2009): 68-76.

"Taiwan Wants to Send Nuclear Waste Overseas for Reprocessing." The Japan Times, February $18,2015$.

Takahashi, Sugio. "Ballistic Missile Defense in Japan Deterrence and Military Transformation." Asie. Visions 59 / Proliferation Papers 44, December 2012.

Takubo, Masafumi. "Wake Up, Stop Dreaming: Reassessing Japan's Reprocessing Program." The Nonproliferation Review 15, no. 1 (March 2008): 71-94.

Takubo, Masufumi, and Frank von Hippel. "Ending Reprocessing in Japan: An Alternative Approach to Managing Japan's Spent Nuclear Fuel and Separated Plutonium." International Panel on Fissile Materials, November 2013.

Tatsumi, Yuki, and Robert Weiner. "Political Influence on Japanese Nuclear and Security Policy: New Forces Face Large Obstacles.” Monterey: U.S. Navy Postgraduate School, February 2014.

"Telegram from the Embassy in Japan to the Department of State." In Foreign Relations of the United States 1955-1957, XXIII Part 1, Japan: Document 132. Washington, D.C.: Government Printing Office.

"Telegram from the Embassy in Japan to the Department of State." In Foreign Relations of the United States 1958-1960, XVIII, Japan; Korea: Document 20. Washington, D.C.: Government Printing Office.

"Telegram from the Embassy in Japan to the Department of State." In Foreign Relations of the United States 1964-1968, XXIX Part 2, Japan: Document 37. Washington, D.C.: Government Printing Office.

The Energy and Environment Council, Government of Japan. "Innovative Strategy for Energy and the Environment," September 14, 2012.

"The Text of the Agreement of 4 March 1977 between Japan and the International Atomic Energy Agency in Implementation of Article III 1 and 4 of the Treaty on the NonProliferation of Nuclear Weapons.” INFCIRC/255. International Atomic Energy Agency, March 1978.

"The Texts of Instruments Connected with the Agency's Supply of Uranium to Japan." INFCIRC/3. International Atomic Energy Agency, April 15, 1959. 
“Uranium Supplies: Supply of Uranium.” World Nuclear Association, December 2016. http://www.world-nuclear.org/information-library/nuclear-fuel-cycle/uraniumresources/supply-of-uranium.aspx.

von Hippel, Frank. "Overview: The Rise and Fall of Plutonium Breeder Reactors.” In Fast Breeder Reactor Programs: History and Status, edited by Thomas B. Cochran, Harold A. Feiveson, Walt Patterson, Gennadi Pshakin, M.V. Ramana, Mycle Schneider, Tatsujiro Suzuki, and Frank von Hippel, 1-16. International Panel on Fissile Materials, 2010.

Walt, Stephen M. “International Relations: One World, Many Theories.” Foreign Policy, no. 110 (1998): 29-46.

Waltz, Kenneth N. “The Emerging Structure of International Politics.” International Security 18, no. 2 (Fall 1993): 44-79.

. Theory of International Politics. Boston: McGraw-Hill, 1979.

Wendt, Alexander. "Anarchy Is What States Make of It: The Social Construction of Power Politics." International Organization 46, no. 2 (Spring 1992): 391-425. 